Bojan Krstić ${ }^{1}$

University of Nis, Faculty of Economics

Milos Krstić ${ }^{2}$

Research Associate at the University of Nis,

Faculty of Science and Mathematics
ORIGINAL SCIENTIFIC ARTICLE doi:10.5937/ekonomika1504001K

Received: October 06, 2015

Accepted: November 17, 2015

\title{
MODELS OF IRRATIONAL BEHAVIOUR OF HOUSEHOLD AND FIRM
}

\begin{abstract}
To study the basic characteristics of impulsive household, economists use probabilistic different models, These models are stylized and lack many details. Despite the fact that these models lack realism, studying these models will enable economists to see what is really important for them. For example, increasing the relative price of commodity $X$ decrease the consumption of commodity $X$. The model of irrational household behaviour indicates that the irrational economic subjects will be forced to behave as-if rational, i.e. that their behaviour is consistent with the fundamental theorem of rationality of traditional economic science that states: demand curve of rational household have a negative slope. Also, The model of irrational household behaviour indicates that a large number of independent impulsive households gravitate toward the point $p$, which represents the best of choice. This theory is true for irrational firms.
\end{abstract}

Key words: the model of irrational household, the model of irrational firm, the fundamental theorem of rationality, demand curve, the best choice.

JEL classification: A1, D1

\section{МОДЕЛИ ИРАЦИОНАЛНОГ ПОНАШАЊА ДОМАЋИНСТВА И ФИРМЕ ${ }^{3}$}

\begin{abstract}
Апстракт
Да би економисти изучили основне појединости импулсивног домаћинства користе различите моделе. Ти модели су стилизовани и недостаје им мноштво детаља. Упркос мањку реалистичности, проучавање оваквих модела омогућиће економистима да виде оно што је за њих заиста важно. На пример, повећање релативне цене производа X, смањује потрошњу истог. Модел понашања ирационалног домаћинства, према томе, показује да ће ирационални привредни субјекат бити присиьен да се понаша

\footnotetext{
${ }^{1}$ bojan.krstic@eknfak.ni.ac.rs

22krsticmilo3@gmail.com

${ }^{3}$ The paper is the result of the research done as part of the project no. 179066 "Improving the Competitiveness of the Public and Private Sector by Networking Competences in the Process of the European Integrations of Serbia", financed by the Ministry of Education, Science and Technological Development of the Republic of Serbia.
} 
као рачионалан, односно да је његово понашање у духу фундаменталне теореме рационалности традиционалне економске науке која гласи: крива тражне рационалног домаћинства има увек негативан нагиб. Поред тога, модел понашања ирационалног домаћинства указује да већина независних импулсивних домаћинстава гравитира ка тачки п која представља најбољи избор. Ова теорија важи и за ирационалне фирме.

Кључне речи: модел ирационалног домаћинства, модел иращионалне фирме, фундаментална теорема рационалности, крива тражње, најпожељнији избор.

\section{Introduction}

Economic theory is inhabited by a specific type of organism, which we sometimes call homo economicus. Members of the species are always rational. As the managers, they maximize profit, as consumers they maximize their utility or equivalently, they choose the point on the highest indifference curve. In addition to the constraints they are faced with, participants rationally measure all the costs and benefits and they always choose the best possible course of action (Menkju, 2007).

The actual people are, however, homo sapiens. Although they largely resemble to rational, calculating people who are assumption of economic theory, they are away from more complex creatures. They can be "forgetful", "sudden", "confused", "emotional" and "myopic". These deficiencies in human reasoning represent the most important topics of psychologists' studies which economists had ignored until recently (Menkju, 2007).

Herbert Simon, one of the first psychologists who studied the border areas of economics and psychology, proposed that firms and households cannot be observed as rational actors who maximize their utility, but as subjects who satisfy their needs and desires. Simon refuses the maximization hypothesis, but retains the rationality assumption. Actors cannot get all the necessary information and to process them, but they can still make rational decisions within a limited set of alternatives. Thus, firms and households are not characterized by "maximizing" but "satisficing" behaviour (Krstić \& Krstić, 2015).

The aim of the paper is to explain when we can expect from an irrational economic entity (firms and households) to be forced to behave rationally, or "as if" its decisions were rational, instead of impulsive, for instance. In this paper, we will discuss the characteristics of the model of irrational household behaviour. Furthermore, we will present the model of irrational firm behaviour.

\section{The model of irrational household behaviour}

Herbert Simon, Richard Curt and James Marcus have proved that firms and consumers do not behave in a "maximizing", but "satisficing" fashion (Simon, 1991; Marcus, 2004; Robles, 2007). Firms and households tend to realize a particular acceptable minimum (Simon, 1982). "Satisficing strategies" can often be effective. However, this strategy gives good results if we adequately collect and process information (Simon, 1961). From Geoffrey Hodgson's perspective, the key source of satisfying behaviour 
is not located in the deficit of information (the missing information) or the institutional constraints, but the main source of satisficing behaviour is located in the excess of information in relation to the power of capacity of rationality (Hodgson, 2012). If the members of the household have the imperfect mental abilities and the decision-making process takes place in complex and changing environment, the ability to adapt to change is relevant criterion of rationality. In this case, routines, habits and informal rules have an important role in the behaviour of household (Hodgson, 2016).

To gain an understanding of the model of satisficing household behaviour, it is necessary to firstly considered models of maximizing action. The model of maximizing action is based on the postulate which states: the behaviour of can be described by saying that household always chooses the combination that maximizes its utility or satisfaction, between all collections of goods that it can buy (Varijan, 2014). Figure 1 shows the diagram with a price for commodity $Y$ on the vertical axis and a price for commodity $X$ on the horizontal axis. By using this diagram, we can determine the best choice household.

Figure 1: Model of maximizing action

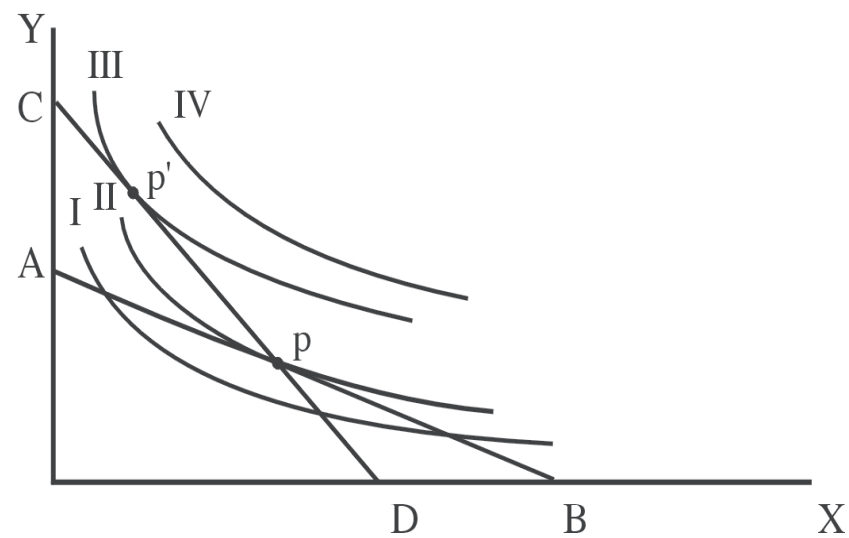

Source: Becker, G., 2009). Irrational Behaviour and Economic Theory, Chicago Journal, Chicago p. 3

The line $A B$ is a budget constraint and surface $O A B$ is the consumption opportunity set ( set of available combinations of $X$ and $Y$ ). Indifference curve (which connects the different collection of goods with the equal utility) shows the internal preferences of household's members (Labus 2003). The household realises the best choice at the point $p$, i.e on the intersection between the budget line $A B$ and indifference curve $i i$ (Becker, 2009 ).

In this collectivist-based model, with a shift of the budget line from $A B$ to $C D$, the price of commodity $X$ is increased. According to the usual analysis of supply and demand, the price of commodity $Y$ is fallen. The optimal choice shifts from point $p$ to point $p$ '. This change indicates that household increases consumption of commodity $Y$ on account (of) consumption of the commodity $X$. If the fundamental theorem of traditional econimics science - the demand curve has always a negative slope, if a large number of factors that influence on consumer decisions, except price, remain unchanged - is true, reducing the price of commodity $Y$ decreases demand for the commodity $X$ (Becker, 2009).

Studying the amount of income that households spend on any kind of quantity of commodities is based on some the theorems of traditional economic science. For 
example, "decrease in real income necessarily decreases the amount spent on at least one commodity, and the average present age change in expenditure on all commodities must equal the percentage decrease in income" (Becker, 2009 (1962), 4). These theorems are largely independent of the decision rule. This will ease the modelling of behaviour and solving real economic problems of household (Гилбоа et al., 2015).

In Figure 2, the relationship between a consumption and an available income (a budget constraints) is shown. The change in the budget line (people change their the budget line from $A B$ to $C D$ ) would decrease consumption of commodity $X$ and increase consumption of commodity $Y$. In this way, the opportunity set $O C D$ is obtained. This opportunity set is limited by the budget line $C D$ and it offers "more opportunity to consume $Y$, and less opportunity to consume $X$ than does set $O A B$ " (Becker, 2009, 4). Since the point $p$ represents the quantity of commodities $X$ and $Y\left(X_{0}\right.$ and $\left.Y_{0}\right)$, which would be chosen in the space (set) $O A B$ by the particular decision rule, the surface $O C D$ offers a smaller opportunity to consume more than $X_{0}$ of $X$, on the one hand, and the greater opportunity to consume more than $Y_{0}$ of $Y$, on the other hand. The application of the particular decision rule will ensure that households choose the quantity of commodity $X$ to the left from the $X_{0}$ and the amount of commodity $Y$ to the right from $Y_{0}$ within the consumption opportunity set $O C D$. This is perfectly consistent with the idea that the quantity is positively correlated with the total benefit.

Figure 2: Model of maximizing behaviour of household - the impact of relative prices on the equilibrium of a household

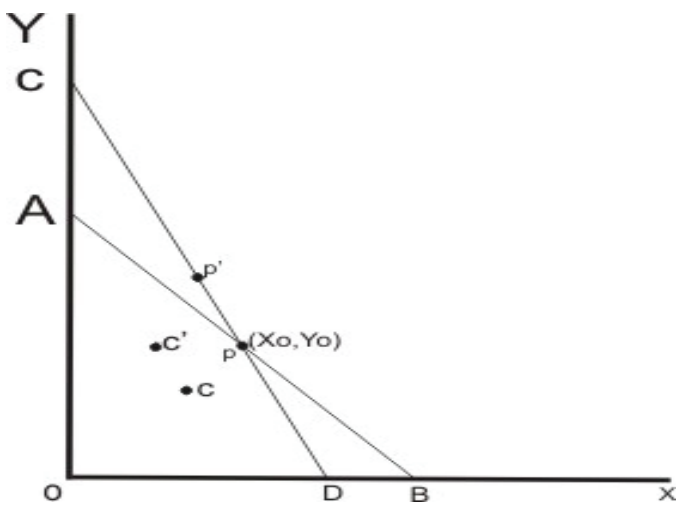

Source: Becker, G., 2009 (1962). Irrational Behaviour and Economic Theory, Chicago Journal, Chicagop. p.5

According to Becker, it does not matter whether a participant realized the maximum value of the goal function or not?, for analysis of rational behaviour, but it is important that the participant's is behaviour consistent with the fundamental theorem of rationality that states: demand curve for any commodity must be negatively inclined (Becker, 1957, p. 2-3). Becker recognizes that rational behaviour is not necessarily selfish behaviour. The altruistic (selflessly or irrational) behaviour can be classified as rational. As the negative slope of the demand curve is a demonstration that household acts rationally, we conclude that irrational household, which has a negative sloped demand curve will be rationally. Becker has identified two extreme types of irrational behaviour: impulsive and inert behaviour. Between these two extremes lies a wide spectrum of altruistic forms of action (Krstić \& Krstić, 2015). 
Impulsive behaviour is reduced to the random change of behaviour, and inert (routine) behaviour excludes any changes in behaviour (regardless of environmental conditions). To study the basic characteristics of impulsive behaviour, economists use probabilistic model, in which each solution is assigned a number from the interval from 0 to 1 . Inert behaviour is represented by a model in which participants' decisions determined by the previous knowledge and experience (Becker, 2009). These models are stylized and lack many details. Despite the fact that these models lack realism, studying these models will enable economists to see what is really important for them (Гилбоа et al., 2015).

These models simplify irrational behaviour of a household. Thus, the fundamental theorem is related to the impulsive behaviour, at least in the case of a market with a large number of participants. In the model of irrational behaviour, impulsive household forms a negatively sloped demand curve. By increasing the relative price of commodity X, the structure of the budget space is changed at the expense of reducing the consumption of commodity X. Generally speaking, it can be expected that the irrational economic subjects will be forced to behave as-if rational, or as if its decisions are rational, and they are not, for example, impulsive.

The assumption is that the impulsive households behave according to pattern "asif ". This means that the household's action does not depend $\mathrm{n}$ the utility function of a single member, but from a probability mechanism. In the model of impulsive behaviour, the number of completely inefficient households would assign equal probabilities all points in the opportunity set (including points in inside of the consumption opportunity set, regardless the fact that only the points on the budget line have probability of being selected). Although the consumption of household could not be determined in advance, the average consumption of a large number of independent impulsive households gravitates toward the middle at the budget line, which also represents the amount of expected consumption. When the consumption opportunities were initially limited to the budget line $\mathrm{AB}$ (Figure 2), the average consumption of households would be close to the point $p$ that lies at the middle of the line $\mathrm{AB}$, while other households uniformly distributed around the point $p$.

A changes in relative prices rotate the budget line $\mathrm{AB}$ around the point $p$. This point represents the consumption of household that contributes to the realization of the interests of the household, in the best way. The line $C D$ shows a compensated increase in the price of commodity $\mathrm{X}$, so now the household chooses a point on the line $C D$ rather than (a point) on the line $A B$. A single household can choose any point on the line $C D$, but the average location of many independent impulsive households would almost certainly be somewhere at the middle, around the point $p$ ' on the budget line $C D$. It is clear that the point $p$ ' is not to left and above the $p$ by accident: a compensated increase in the price of commodity $X$ shifts the midpoint of the budget line to the left and upward, while a compensated decrease shifts it to the right and downward. Finally, Becker concludes that the fundamental theorem of the rational behaviour, that the demand curve is negatively inclined, takes into account impulsive behaviour. The expected demand curve of individual household also has a negative slope. The cause of the negative slope of both expected individual and actual market demand curves is price that influence on the distribution of total consumption.

Consider now a model of inertia in which the utility of the household in any period depends not only on consumption in this period, but also from previous spending (Krstić, 2013). The point $p$ (Figure 2) again represents the average consumption of large groups of households that are faced with the budgetary constraints $A B$, while the budget constraint $C D$ is the result a compensated increase in the price of the commodity $X$. Households, who 
are initially distributed in the region $A p$ (Figure 2) do not change their budget constraint (in any period) after the price changes. Households, who are initially distributed in the half open region $p B$, change their the budget constraint after prices changed because the line $p B$ would be outside the new opportunity set $O C D$. Clearly, households who are forced to adjustment are not accidentally just those whose consumption of commodity $X$ is above the average: increasing price of commodity $X$ changes the structure of the consumption opportunity set at the expense of reducing the consumption of the same. If the average household with the budget constraints $p B$, spends more commodity $X$ than the line $C D$ permits, then average consumption of commodity $X$ is reduced. If the line $A p$ is not changed, households with the budget line $p B$ reduce consumption of commodity $X$, since the line $O D$ offers an opportunity to accomplish maximum consumption of commodity $X$ with the budget constraint $C D$. In general, large changes in relative prices and the wide distribution of households increase the probability that, with the new the budget line, the maximum consumption of commodity $\mathrm{X}$ will be lower than the average consumption at the level of the $p B$ line. Although the adjustment made by households on the $p B$ line cannot be accurately illustrated, their consumption is likely to decrease.

In the model of irrational household, an actual choice is based on a prior behaviour and probability theory. The choices of impulsive and inert households caused the emergence of the average results (outcomes). Since these subjects tend to form negatively sloping demand curve, market demand curve of impulsive and inert households have a negative slope. Therefore, all forms of irrational behaviour reproduce the fundamental theorem of rational behaviour. Households, who tend to maximize the quantity of goods, have a negatively inclined compensated demand curve, as well as the consistent and transitive preference system. It is important to point out that the rationality of the market does not depend on the rational behaviour of individual actors. In other words, a market with a large number of irrational households will form a negative declining demand curve (market will be rational function) (Krstić \& Krstić, 2015).

The behaviour of inert household in the market depends on both their dispersion and changes in market prices as well as the reactions of households which forced to adjust. If the price of $X$ increases by 10 per cent and if households were uniformly distributed along the initial budget line subjects forced to adjust reduce the average consumption to the midpoint of the budget line, total demand is reduced by 30 per cent, and the value of elasticity of 3 (Becker, 2009 (1962)). A small change of price or larger dispersion would provide higher elasticity (of demand). In this regard, it is important to point out that a large group of erratic households can form a unitary elastic demand curve. With a shift the budget line from $A B$ to the $C D$, inert households in Figure 2 shift from the boundary toward the interior of region $A p$. Since a goods are precisely specified, households are located on the boundary of the region $A p$, According to Becker, this is usually understood as an additional implication of rationality (Becker, 2009, 7).

This utility-maximizing households lie on the boundary of the opportunity set because they accomplish the maximum their utility in this way (as long as the marginal utility of at least one commodity was non-negative). "Even if expenditures were defined so that the total income had to be spent, irrational households might not consume the entire amount because some commodity might be lost, spoil or accumulate unused" (Becker, 2009, 9). In addition, inefficient impulsive households might assign equal probability to (the importance of) all points in the opportunity set, not just to those on the boundary. The average consumption of the largest number of such households would be at the centre of opportunity set, with households uniformly distributed around this point . 


\section{The model of irrational firm behaviour}

To gain an understanding of the model of irrational firm behaviour, it is necessary to firstly considered the model of rational firm behaviour. The behaviour of rational firm can be graphically illustrated by Figure 2. The graph looks like the graph in Figure 2, but with the isocost lines instead of the budget lines in the space between the abscissa and ordinate. An available quantity of commodity $Y$ is illustrated in the ordinate, the available quantity of the commodity $X$ is illustrated in the abscissa. The increasing price of the input $X$ decreases the quantity of this input in the production process, with a given level of total costs. The isocost $C D$ of the rational firm shows reducing the quantity of input $X$ in relation to the isocost line $A B$. However, the "irrational companies" tend to react rationally to changes in input price. Thus, most of the "impulsive firms" would certainly be at the point $p$ (Figure 2), when they faced with the isocost line $A B$, i.e. the $p$ ', to the left and above the $p$, when they faced with the isocost line $C D$.

The traditional distinction between households and firms indicates that firms should not be subject to budgetary constraints if the assumption that the firm chooses the one mode and scope of action that will provide greater profits than any other possible choices is true (Becker, 2009, 11).

According to Becher, the great achievement of "survival" argument, improved by Alhainen and his colleagues (Alchian 1950; Fridman, 1953), is not a demonstration that the firms will survive, if they maximize the profit, but a rather demonstration that the decisions of irrational firms are conditioned by a budget constraint. Really the "survival" argument is simply a special case of a general argument linking the behaviour of all economic subjects to the distribution their opportunities. Therefore, the firms that are unable to achieve continuous production cannot survive on the market and realize negative profits until the available resources are finally consumed. For the same reason, households cannot continually spend, and survive outside their capacities.

Figure 3: The model of behaviour of rational firm

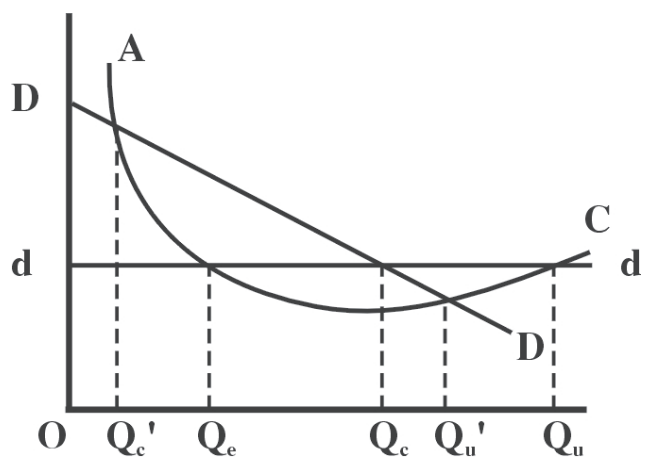

Source: Becker, G., 2009 (1962). Irrational Behaviour and Economic Theory,

Chicago Journal, Chicago, p. 11.

Since space, that is limited by the axes and the budget lines is known as the consumption opportunity set of household in the professional literature, the region of non-negative profit can be represented as the production opportunity set of the firm. For example, a household with the budget line $A B$ has the consumption opportunity set $O A B$ 
(Figure 2), and a firm with the average cost curve $A C$ and demand curve $d d$ (Figure 3 ) has the production opportunity set $Q_{e} Q_{u}$. Just as a household makes decisions about amount of income, that it can spend, analysing all combinations of goods that it can buy (from their income and given prices), so a firm plans the output, taking into account the fact that invests no more than the realized profit (that is, it cannot live beyond its opportunity).

The entire amount would be spent at the output that yield (yielding) zeroes profits; nothing would be spent if profits were maximized; and a positive, but less than the total amount would be spent at the other available output. The traditional conclusion that firms are not the subjects to budget constraints is made valid when profits are maximized: nothing will be spent and so no budget constraints. If any other decision is conducted, something would be spent and will exert a budget constraint will exist. Changes in the cost or production conditions would change the production opportunity set, and force even irrational firms to respond systematically. Many variables influence on the production opportunity set? Regarding the difference between monopolistic and competitive phenomena, the authors stress a well-known theorem that is closely associated with maximizing behaviour, and even economists can be impressed by demonstrated a wide interval of irrational behaviour would reproduce this theorem.

Industrial costs would be the same as firm's costs in industries that have a lot of independent, identical firms, but the industrial demand would be more elastic than firm's demand. Therefore, the curve $A C$ in Figure 3, can, represent both industry and firm average costs, $D D$ industry and dd firm demand conditions. the line $D D$ is drawing so firm achieves a balance at a price $O d$, and the output $O Q C$, where the marginal cost equals price. If the industry becomes fully monopolistic cartel, then $D D$ measures both industrial and firm demand, while $d d$ would no longer be relevant. The famous old theorem says that if firm constantly maximizes profit, output member of the cartel would be less than $O Q C$.

Completely impulsive firms would assign an equal probability to all available outputs and choose one of them randomly. Cartelization would shift the firm's demand curve to $D D$ and shifts the opportunity set from $Q_{e} Q_{q}$ to $Q_{e}{ }_{e} Q^{\prime}{ }_{u}$. If the output were again selected randomly, firms would be uniformly distributed along $Q_{e}{ }_{e} Q^{\prime}{ }_{u}$ and the average output would almost certainly be at the midpoint that is to left of $O Q_{c}$. Also, it can be shown that the inert and many other irrational firms reproduce this famous theory of neoclassical economists. The transition from competition to monopoly shifts the production opportunity to lower output, which in turn encourage irrational companies to reduce their activities.

Discussion about the input price and the degree of competition indicates that "irrational firms" can produce very rational market responses, and this, seeming paradox, offers the solution to boiling and protracted controversy between marginalnists and anti-marginalists. Confidence in the irrationality of firms affected the anti-marginalists to conclude that the response of the market was also irrational, while confidence in the rationality of the market contributed to the view of marginalists that (in these circumstances) and rational firm. 


\section{Conclusion}

To gain an understanding of the model of behaviour of irrational household it is necessary to firstly considered the model of rational behaviour of household. From the viewpoint of this model, rational household always chooses the combination that maximizes its usefulness or satisfaction. Figure 1 represents the diagram that enables to find the best choice of household. The abscissa shows the quantity of commodity $X$, and the ordinate shows the quantity of commodity $Y$. Line $A B$ is a budget constraint and surface $A B$ is a set of available combinations of commodities $X$ and $Y$. The indifference curve does not only connect the different combinations of goods with the equal degree of usefulness or satisfaction, but also shows the preferences of household members.

Household accomplishes the best choice at the point $p$, at the intersection between the budget line $A B$ and the indifference curve $i$.

Firstly, increasing price of commodity $X$ shifts a budget constraint from $A B$ to $C D$. Secondly, it increases the consumption of commodity $Y$ at the expense of consumption commodity $X$. Thirdly, increase in price of commodity $X$ creates a new consumption opportunity set. This means that choice of household depends on the price. The price forces households to behave in accordance with the fundamental theorem of rationality: demand curve has always negative slope, assuming that the other factors, that influence on household's demand are not changed.

Becker has identified two extreme types of rational behaviour. It is impulsive behaviour, that Becker reduces to the random change of behaviour, and inert (routine) behaviour, that excludes any changes in behaviour. Becker proved that an irrational firm may act as a rational one, i.e. as if its actions were rational, instead of impulsive.

When the consumption opportunities were initially limited by the budget line $A B$, the average consumption of a large number impulsive households gravitates toward the point $p$. This is an indicator of their rationality. On the other hand, the average consumption of other impulsive households is uniformly distributed around the point $p$. This, further, means that these households can assign equal probabilities to all points in the entire consumption opportunity set. This is considered an indicator of their irrationality.

To gain an understanding of the model irrational behaviour of firm, it is necessary to firstly considered the model of rational behaviour of firms. Increasing prices of inputs $X$ would reduce the quantity of inputs in the production process within the firm (Figure 2 ). The isocost line $C D$ of rational firm shows reducing the quantity of input $\mathrm{X}$ in relation to the isocost line $A B$. This theory is true for irrational firms. A large number of impulsive firms would certainly be at the point $p$ when faced with $A B$, that is $p^{\prime}$, to the left and above the $p$, when faced with $C D$.

\section{References}

Alchian, A. (1950). Uncertainty, Evolution and Economic Theory. Journal of Political Economy, 58 (3), 211-221.

Becker, G. (1962). Irrational Behaviour and Economic Theory. Journal of Political Economy, 70(1), 1-13.

Becker, G. (1957). The Economisc of Discrimination. Chicago: USA: University Press.

Friedman, M. (1953), The Methodology of Positive Economics in Essays in Positive Economics. Chicago, USA: University of Chicago Press. 
Hodgson, G. (2005). From Pleasure Machines to Moral Communities: An Evolutionary Economics without homo economicus. Chicago, USA: University of Chicago Press.

Hodgson,G. (2006). Economics in The Shadows of Darwin and Marks. London, UK: Edward Elger.

Hodgson, G. (2012). On the Limits of Rational Choice Theory. Economic Thought, 1 (1), 94-108.

Krstić, B., Krstić, M. (2015). Rational choice theory and random behaviour. Ekonomika, 61 (1), 1-15.

Krstić, M. (2013). Teorija racionalnog izbora i zavisno ponašanje. Sociološki pregled, 47 (4), 515-536.

Labus, M. (2003). Osnovi ekonomije. Beograd, Stubovi kulture.

Marcus, J. (2004). The birth of the mind: how a tiny number of genes creates the complexities of human thought. New York, USA: Basic Books.

Mankju, G. (2007). Osnovi principi ekonomije. Beograd, Centar za izdavačku delatnost.

Robles, J. M. (2007). Bounded rationality: A realistic approach to decision process in a social enviroment. Theoria, 16 (1), 41-48.

Simon, H. (1991). Bounded Rationality and Organizational Learning. Reflections, 1 (2), 17-29.

Simon, H. (1982). Theories of Decision Making in Economics and Behavioural Science. The American Economic Review, 49 (3): 253-283.

Simon H. (1961). Administrative Behaviour. New York, USA: Simon \& Schuster.

Varijan, Н. (2014). Mikroekonomija. Beograd, Centar za izdavačku delatnost.

Гилбоа И., Постлуэйт Э., Самуэльсон Л., Шмайдлер Д. (2015). Экономические модели как аналогии. Вопросы Экономики, (4), 106-130. 